\title{
Classification and management of community forests in Indian Eastern Himalayas: implications on ecosystem services, conservation and livelihoods
}

Ranjay K. Singh ${ }^{1,2^{*}}$, Shah M. Hussain ${ }^{1}$, T. Riba ${ }^{1}$, Anshuman Singh ${ }^{2}$, Egul Padung ${ }^{3}$, Orik Rallen ${ }^{4}$, Y. J. Lego ${ }^{4}$ and Ajay Kumar Bhardwaj ${ }^{2}$

\begin{abstract}
Introduction: Evidence is mounting that traditional knowledge can play a critical role in shaping the biodiversity conservation strategies and maintaining ecosystem services. This study was conducted with Adi community of Arunachal Pradesh (Ar P) state in the Eastern Indian Himalayas to understand as how local systems of forest classification governs conservation tradition and influences subsistence livelihoods. Twenty Adi villages were sampled from East Siang district of Ar P. A total of 197 men and 204 women (total of 401) Adi respondents were selected for this study. A combination of methodologies including in-depth interview, transect walks, focus group discussion, participant observation and informal interactions were combined for data collection.

Results: Local forests are classified into 10 different categories based on indicators such as topography, cultural significance, use typology, ownership rights and plant diversity indicators. Local people assign different values (economic, cultural and ecological) to different forest types. Overall, morang followed by regpi and homegardens are perceived to be more valuable to the local needs than other forests with relative ranking of a particular forest reflecting its sustainability. Adis access several diverse services from these community-managed forests. Compared to men (3-35\%), the role of women was assessed to be much higher (65 to 100\%) in conserving forest biodiversity. Woman-led practices, instrumental in sustainable forest management, included deliberate manipulations of micro-habitats, sustainable harvesting strategies and species domestication. Men were mostly involved in ownership and decision-making roles and in devising social norms to ensure sustainability. Adi celebrate a number of cultural events to sustain biodiversity. Forest-based livelihoods are intrinsically connected to forest resource conservation and are governed by community approaches. Most of the community members gather plants, hunt wild animals and access other ecosystem services from these forests to sustain their livelihoods. Community-owned forests are collectively managed by an indigenous institution 'Kebang'. Conflicts relating to forest land use and resource management are resolved by the customary chief 'Gaon Burha' and his associates using traditional norms.
\end{abstract}

Conclusions: Adi's system of forest classification, based on ecological, socio-cultural and livelihood indicators, is a location-specific yet comprehensive in nature. Study suggests that integrating the local indicators applied in classifying and strategies applied in managing the local forests can provide valuable insights to the policy makers for the sustainable conservation of forest resources.

Keywords: Adi tribe, Forest classification, Traditional ecological knowledge, Indigenous institutions, Ecosystem services, Conservation, Livelihoods

\footnotetext{
* Correspondence: ranjaysingh_jbp@rediffmail.com

${ }^{1}$ College of Horticulture and Forestry, Central Agricultural University, Pasighat, Arunachal Pradesh 791 102, India

${ }^{2}$ ICAR-Central Soil Salinity Research Institute, Karnal, Haryana 132001, India

Full list of author information is available at the end of the article
} 


\section{Introduction}

Natural resource use including biodiversity management by traditional communities compatible with the local ethos exemplifies a sustainable practice for meeting diverse livelihood needs (Carlson and Maffi 2004; Singh et al. 2015a, 2015b). Social relationships and norms contribute significantly to community-based sustainable natural resource management (Ostrom 1990; Turner 2005; Turner and Clifton 2009). Traditional ecological knowledge (TEK), social institutions and ecological factors greatly influence decision making and modus operandi in community-based natural resource management (Gadgil et al. 2000; Díaz et al. 2011; Elmqvist et al. 2004). In many such natural resource management systems, users often classify natural resources using ethno-taxonomy (Shepard et al. 2001). Globally, an amazing diversity of local practices, protocols and institutions contribute to biodiversity management (Long and Zhou 2001; Berkes 2002). In the recent past, concerns have been raised that local communities must have a say in biodiversity conservation strategies, because conventional 'top-bottom' policies ignoring local concerns have mostly failed to ensure desired results (Díaz et al. 2011). Native and local communities in several remote regions employ the time-tested means and ways to categorizing and managing natural resources for livelihood support. Incorporation of community perspectives and knowledge in forest resource management can contribute significantly to achieve sustainable outcomes (Agrawal and Gibson 1999; Agrawal and Chhatre 2011).

In India, relentless negligence of community concerns has often led to the overexploitation and degradation of natural systems in the past five decades or so (Ramakrishnan 2002). Community-based forest management and natural resource management were under-rated by the policy makers (Ramakrishnan 2002, 2007) until Joint Forest Management (JFM) policy came into being in the year 2000 (Khawas 2003). In many developing countries, the state control over local institutions managing the natural resources is based on the assumption that local resources could not be sustainably managed by the local communities (Agrawal 2005; Ostrom 2003). Since the beginning of this century, international and national institutions are increasingly recognizing the need for incorporating TEK and institutional heritage in biodiversity and natural resource management (Gadgil et al. 2005). Little work on role of community knowledge in classifying local forests and their management has been done in India. In India, there is a pressing need for careful and comprehensive analysis of the TEK-led classification and management of natural resources and forests.

Traditional mountain communities of northeast India, including the Adi tribe, rely heavily on local natural resources for sustaining their livelihoods (Ramakrishnan et al. 1996; Ramakrishnan 2007; Singh et al. 2015a, 2015b).
Interestingly, this dependence often transcends biophysical, ecological and economic realms because socio-cultural and spiritual dimensions also play critical roles in shaping and managing ecosystem functions and services (Singh et al. 2015a, 2015b). Local people have a holistic knowledge of their social-ecological systems resulting in development of climate resilient sustainable agricultural practices and forest management strategies (Poffenberger et al. 2007; Mishra et al. 2011).

The state of Arunachal Pradesh (Ar P) has one of the largest forest covers in India (80\%), and the forests are largely managed by local communities (FSI 2013). Other than reserved forests, a large extent of 'un-classified' forests (62\%) (Poffenberger et al. 2006, 2007) are managed by 26 major tribes of the state unique in terms of their indigenous ways of classifying and managing the local forests. Each tribe has conventional multi-tier institutions that regulate forest management and devise norms for using forest resources (Ramakrishnan et al. 1996; Singh et al. 2015a, 2015b). Of late, local communities' participation in sustainable management of forest resources is increasingly being emphasized. In order to achieve synergy with government policies for forest management, local community institutions and knowledge systems need to be understood in detail.

This study, conducted with Adi tribe in the northeastern Indian state of Ar P, reveals how TEK is being applied in classifying and conserving forest resources for sustainable livelihoods. We carried out this study with the objectives: (i) to assess Adi's TEK applied in classifying and valuing forestlands, (ii) to develop better understanding of Adi's indigenous system of community forest lands use, (iii) to identify important ecosystem services associated with community forests, and (iv) to understand the trends in the use of socio-cultural capital in sustainable forest resource management.

\section{Research methodology Description of study area}

Arunachal Pradesh (Ar P) state lies between $26^{\circ} 28^{\prime}$ and $29^{\circ} 30^{\prime}$ north latitudes, and the $90^{\circ} 30^{\prime}$ and $97^{\circ} 30^{\prime}$ east longitudes. It is a mountainous region with great altitudinal variation. At lower elevations, climate is humid, and the valleys are covered by swampy rainforest, particularly in the eastern part. In contrast, climate is cool and snowfall occurs during winter at higher altitudes having mixed forests consisting of pines, oak and rhododendron. In addition to over 5000 species of flowering vascular plants, an array of ferns, liverworts, lichens, fungi and algae are found in Ar P. The forest ecosystems of the state are classified into six major categories: tropical, subtropical, temperate, sub-alpine and alpine vegetation, secondary forests and aquatic vegetation with each type 
comprising of several subtypes based primarily on altitude and climatic factors (Kaul and Haridasan 1987).

The state's population predominantly consists of 26 major tribes and about 110 ethnic groups, constituting $63.7 \%$ of the total population (2011 Census of India). Most of these tribes are ethnically similar having a common pedigree. However, geographical distance from each other has generated immense variations in language, dressing and customs (Bisht 2008). Adi with its seven major ethnic groups (Bori, Pasi, Padam, Minyong, Milang, Shimong and Pangi) is one of the largest tribal groups ( 0.24 m; CPS 2016). Most of the tribes, including the Adi, practise 'slash and burn' or 'jhum' agriculture (Ramakrishnan 2007). As with other tribes, Adi enjoy traditional rights over lands, water and forests within their jurisdiction. Disputes relating to natural resources are settled at the village level by indigenous institutions. Adi members can freely access ethnobotanicals, animals and other natural resources from the community forests. Adi men and women have distinct roles relating to agriculture- and forest-based activities.

\section{Study approach}

We used a qualitative approach to conduct this study. Community consultation was first established with each village Gaon Burhas (GBs, customary village chief), Co-GBs, elderly persons and socio-cultural experts on biocultural resources. The objectives of this study were explained to the village GB, Co-GBs and other key informants in the beginning. Data were collected through personal interviews with selected male and female members followed by focus group discussions (FGDs) and informal interactions and participants' observations on local forests, classification and management systems, related socio-cultural institutions and practices. Periodic village meetings and workshops were also conducted to communicate the study results to participants to incorporate their feedbacks into data collection process.

\section{Sampling method}

Following a purposive sampling method, East Siang district was selected on the basis of forest cover, ethnicity, institutional and cultural diversity and people's dependence on forest resources. Three circles (administrative units) were chosen from the district, again purposively, following the same criteria adopted in selection of the district. Then, based on the Adi tribe's culture and close relationship with nature, 20 villages from three purposively selected circles were sampled. While selecting the villages, both traditional (remote villages) and transitional (near Pasighat town) societies were surveyed to understand the variations in forest-based institutions and related knowledge and practices. From these villages, 197 man and 204 woman (total 401) respondents of various ages and resource endowments were selected with the help of GB (see sampling details in the Additional file 1:
Table S.1 in S1). The 21 GBs and 63 Co-GBs from 20 villages were also sampled (see Additional file 1: Table S.2 in S1).

\section{Method of data collection and measurement of variables}

Field studies were conducted over a 3-year period (January 2006 to December 2008). A follow-up regional workshop was organized in March 2009. Other related activities were carried out (online mode) up to 2016. Study was conducted with the help of two local field assistants well versed in Adi dialects, customs and socio-political systems. After 3 years of initial participatory work, the first author (RKS) developed a good understanding of local dialects enabling direct contact with Adi members for further data collection through several steps (described in Additional file 1: Table S.3 in S1). A combination of methodologies (listed in Additional file 1: Table S.4 in S1) was used for collecting data. In addition, several transect walks were conducted to forests, especially to understand the nature of disputes related to land and forest resources and the approaches to resolve them in Kebang (local village court). Results from these investigations were later used to help formulate open-ended questions for the interviews.

Following the participant observation approach, RKS stayed in Adi houses in forest areas to gain experience on patterns of forest resource use for understanding the entire dynamics of local forest classification system and resources. Subsequently, interviews were conducted using a semi-structured schedule to gain detailed information. Study sites and objects were extensively photo and video-graphed to supplement the data acquired through other means. The GB and Co-GB of each village were interviewed to incorporate their perspectives in the study. Members of natural resource user groups such as hunters (12) and plant harvesters (key men and women members from each village), traditional healers (8) and fishermen (7) were also interviewed and invited to participate in focus group discussions (FGD) (two in each village).

Taking insights from Sangha and Jalota (2005) and Dai et al. (2017), subsistence, economic, cultural and ecological values of each forest typology were assessed qualitatively through FGD with Adi members asked to assign scores between 1 and 10. Consensus-based scores assigned by participants were based on variations in biophysical attributes and the corresponding indicative factors associated with a particular forest type (see details in Additional file 1: Table S.5 in S1). The scores assigned by participants to a particular value under a specific forest typology were then synthesized following thematic patterns (Braun and Clarke 2006; Stringer et al. 2017) to calculate the final scores and ranks to draw valid inferences. We measured the ecosystem services using broad indicators including provisioning, regulating and supporting roles, and cultural services as described in Brown et al. (2014) and Orchard et al. (2016). Any 
ambiguities that emerged during the analysis of results were clarified subsequently with key informants over phone. Results of study were shared and discussed with study participants for validation.

\section{Data analysis}

The qualitative data collected through personal interviews were transcribed and combined with information already noted in the field diary during FGDs, audio-recording, informal interactions and participant observations (Huynh and Stringer 2018). Frequency figures of responses recorded in the interview schedule were entered into a spreadsheet. Data were analyzed qualitatively using thematic coding approach (Braun and Clarke 2006; Stringer et al. 2017) with support from descriptive statistics to draw conclusions.

\section{Results}

\section{Local classification of forest areas}

Adi community classifies the community forestlands into various categories based on use, management and accessibility. Taking landscape and topography as the broad indicators, the Adi further classify local forests into 'dite yomrang' (forest in mountainous areas) and 'mootam yomrang' (forest on the plains) categories. While classifying the local forest into 10 categories, Adi consider 15 distinct indicators (Table 1) spanning biotic (e.g. plant and animal richness), physical (e.g. soil solour, fertility, topography and water bodies), socio-cultural (fishing and hunting), economic (timber and non-timber forest products extractions), socio-political (type of ownership) and livelihood-oriented (agriculture related) aspects. Based on these indicators, they distinguish healthy and productive forests from the less productive ones so that appropriate management practices (at individual, clan or community level) are implemented to ensure sustainable harvests.

\section{Perceived values of locally classified forests}

On the basis of scores assigned for subsistence, economic, cultural and ecological values, we could discern different types of local forests (Table 2). Thematic patterns indicated that Adi assigned higher subsistence values to morang followed by regpi, homegardens and mosam forests (Table 2). In contrast, orange and pineapple gardens followed by homegardens and monku forests were perceived to be of high economic value. Cultural and ecological values were highest for morang followed by regpi. Based on overall value including subsistence, economic, cultural and ecological spheres, morang was adjudged to the best forest type followed by regpi, homegardens, mosam and sirung (Table 2). Although both Adi men and women assigned the highest values to morang, they employed different value dimension to arrive on the respective scores (Fig. 1). For instance, men found morang to be a fertile hunting ground while women accessed most of the food and ethno-medicine from morang. Despite the highest score assigned to the morang, most of the respondents opined that intangible services of other forest types should not be overlooked because they provide numerous ecological goods, fulfill cultural needs and reduce the livelihood risks.

\section{Indigenous systems of accessing community forest and jhum lands}

Social structure of Adi villages revolves around the control over jhum lands and community forests. Although jhum lands (regpi) are held as a common property, household use rights continue to be in place since antiquity and jhum lands are inherited by the family descendants. The head priest of the village is given preference while selecting forest lands for shifting agriculture. The priests are also responsible for prayers and rituals to ensure good forest growth and bumper harvests. Traditionally, village Kebang (socio-political indigenous institution) organizes the community meeting to allot Jhum lands to those in need.

While making decisions on jhum land allotment, the Kebang members thoroughly discuss factors like distance of the site from the farmer's residence, economic status of the farmers, family type (joint and nuclear), quality of land and forest and total number of family members. In this exercise, more weightage is given to the poorest individual for his/her livelihood security. It also ensures that rich farmers do not exploit the poor farmers and also helps minimize disputes over land rights as reported by majority of GBs (77.4\%). If two farmers claim for the same plot and a mutual agreement is not reached, then GB will not allow either to use the land. Ancestral rights on jhum lands are usually divided when a married son leaves his parental home to establish his own household.

A person interested in jhum cultivation, but not having a suitable forest land, will contact the one who does to request for transferring the rights to use a particular piece of land. Based on a common understanding, land rights are usually transferred to the needy in anticipation that he will return the land in question to the original owner as and when required. Similarly, while constructing the houses and fencing the agricultural lands, a farmer lacking access to toko-patta (Livistona jenkinsiana Griff) leaves and bamboo stems will contact a person possessing these resources. The person in need is usually granted permission to harvest these materials free of cost, but is expected for a reciprocal gesture.

Socio-political institutions, forest resource management and biodiversity conservation

The hierarchical institutional arrangements consisting of the village GB, 3-4 Co-GBs and other elders of the society, 
Table 1 Indigenous knowledge of classifying local forest by Adi tribe

\begin{tabular}{|c|c|c|c|c|c|c|c|c|c|c|}
\hline \multirow{2}{*}{$\begin{array}{l}\text { Indigenous } \\
\text { indicators }\end{array}$} & \multicolumn{10}{|c|}{ Indigenous forest typology } \\
\hline & Morang & Regpi & Monku & Mosam & Sirung & $\begin{array}{l}\text { Home } \\
\text { garden }\end{array}$ & $\begin{array}{l}\text { Orange } \\
\text { garden }\end{array}$ & $\begin{array}{l}\text { Pineapple } \\
\text { garden }\end{array}$ & $\begin{array}{l}\text { Traditional } \\
\text { tea garden }\end{array}$ & $\begin{array}{l}\text { Village boundary } \\
\text { forest }\end{array}$ \\
\hline Plant richness & Very high & High & High & Medium & High & High & Poor & Medium & Medium & High \\
\hline Animal richness & Very high & Medium & High & Poor & Medium & Nil & Nil & Nil & Medium & High \\
\hline Soil color & $\begin{array}{l}\text { Brown to } \\
\text { reddish }\end{array}$ & Brown & Brown & $\begin{array}{l}\text { Deep } \\
\text { brown }\end{array}$ & $\begin{array}{l}\text { Brown to } \\
\text { reddish }\end{array}$ & Brown & Blackish & Brown & Reddish to brown & Reddish \\
\hline Soil fertility & Very high & Very high & Very High & Medium & $\begin{array}{l}\text { Medium } \\
\text { to low }\end{array}$ & Medium & High & Medium & Medium & High \\
\hline Topography & $\begin{array}{l}\text { Highly } \\
\text { uneven }\end{array}$ & $\begin{array}{l}\text { Highly } \\
\text { uneven }\end{array}$ & Uneven & $\begin{array}{l}\text { Slightly } \\
\text { uneven }\end{array}$ & Uneven & $\begin{array}{l}\text { Plain to } \\
\text { uneven }\end{array}$ & Uneven & Uneven & Uneven & Highly uneven \\
\hline Water bodies & Available & Somewhere & Somewhere & Available & Available & $\begin{array}{l}\text { Not } \\
\text { available }\end{array}$ & $\begin{array}{l}\text { Not } \\
\text { available }\end{array}$ & $\begin{array}{l}\text { Not } \\
\text { available }\end{array}$ & $\begin{array}{l}\text { Not } \\
\text { available }\end{array}$ & Somewhere \\
\hline $\begin{array}{l}\text { Fishing } \\
\text { opportunity }\end{array}$ & High & Medium & Low & Very high ${ }^{c}$ & $\mathrm{Nil}$ & Nil & Nil & Nil & Nil & Low \\
\hline $\begin{array}{l}\text { Disturbance } \\
\text { regime }\end{array}$ & Low & $\begin{array}{l}\text { Jhum } \\
\text { cultivation }\end{array}$ & $\begin{array}{l}\text { Least } \\
\text { disturbed }\end{array}$ & $\begin{array}{l}\text { Rice } \\
\text { cultivation }\end{array}$ & $\mathrm{Nil}$ & $\mathrm{Nil}$ & $\begin{array}{l}\text { Crop } \\
\text { cultivation }\end{array}$ & $\begin{array}{l}\text { Crop } \\
\text { cultivation }\end{array}$ & $\begin{array}{l}\text { Least } \\
\text { disturbed }\end{array}$ & Low \\
\hline $\begin{array}{l}\text { Commercial } \\
\text { agriculture }\end{array}$ & $\mathrm{Nil}$ & High & Nil & Medium $^{d}$ & Least & Subsistence & Very high & Very high & Subsistence & Nil \\
\hline $\begin{array}{l}\text { Subsistence } \\
\text { agriculture }\end{array}$ & $\mathrm{Nil}$ & Very high ${ }^{b}$ & $\begin{array}{l}\text { High to } \\
\text { medium }\end{array}$ & $\begin{array}{l}\text { High to } \\
\text { medium }\end{array}$ & $\mathrm{Nil}$ & Very highe & Very low & Very low & High & Nil \\
\hline Ownership & $\begin{array}{l}\text { Clan and } \\
\text { individuals }\end{array}$ & $\begin{array}{l}\text { Individual } \\
\text { to clan }\end{array}$ & $\begin{array}{l}\text { Clan and } \\
\text { individuals }\end{array}$ & Clan & $\begin{array}{l}\text { Clan and } \\
\text { individuals }\end{array}$ & Individual & Individual & Individual & Individual & $\begin{array}{l}\text { Individual/ } \\
\text { Clan }\end{array}$ \\
\hline $\begin{array}{l}\text { Timber } \\
\text { extraction }\end{array}$ & Very high* & Poor & Very high & $\mathrm{Nil}$ & $\mathrm{Nil}$ & Nil & Nil & Nil & Low & Medium \\
\hline Hunting & Very high & Medium & Occasional & $\mathrm{Nil}$ & Very rare & Nil & Nil & Nil & Nil & Very high \\
\hline $\begin{array}{l}\text { Level of NTFPs } \\
\text { extraction }\end{array}$ & Very high ${ }^{a}$ & High & Medium & Poor & Low & Medium & Nil & $\mathrm{Nil}$ & Low & Very high \\
\hline $\begin{array}{l}\text { Dominating } \\
\text { species as } \\
\text { major indicators }\end{array}$ & $\begin{array}{l}\text { D, Ek, H, } \\
\text { A, F, Cn, R, } \\
\text { WB, OrS }\end{array}$ & $\begin{array}{l}\text { TP } \mathrm{f}^{\mathrm{f}}, \mathrm{IB}, \mathrm{Cn}, \\
\mathrm{B}_{\mathrm{B}} \mathrm{Pd}, \\
\text { Ong, OrS }\end{array}$ & $\begin{array}{l}\text { IB, Ek, H, } \\
\text { A, B }\end{array}$ & $\begin{array}{l}\text { TP, O, } \\
\text { HI, B }\end{array}$ & $\begin{array}{l}\text { B, Ek, } \\
\text { F, Pd }\end{array}$ & TP, Tb, Ong & $\mathrm{TP}$ & $\begin{array}{l}\text { O, TP, WC, } \\
\text { On, B, Ong }\end{array}$ & $\mathrm{TP}, \mathrm{Pd}$ & $\begin{array}{l}\text { A, Cn, D, Ek, I } \\
\text { B, OrS, Pd TP }\end{array}$ \\
\hline
\end{tabular}

Source: Own analysis

Data for this table was collected through focus group discussion (FGD) and personal interview method with selected respondents and key knowledge holders such as Gaon Burha, hunters and healers. Tringulation was made to integrate all the information together

A Anke (wild chestnut), B Belang (Artocarpus heterophyllus), Cn Cane (2-3 species), D Dekang (Gymnocladus assamicus), Ek Ekkam (Phyrinum pubinerve), H Hollok (Bunopithecus hillock), HI Hilika (Terminalia chebula Retz), IB Indigenous bamboos, O Ogjok (Bauhinia variegata), On Onger (Zanthoxylun rhesta), Ong Ongin (Clerodendrum colebrookianum), OrS Orchids (10-15 species), Pd Padanus species, Tb Tambul (areca nut), $R$ Rinko (Coptis teeta Wall),

TP Toko-patta (Levistona jenkinsiana), WB wild bananas, WC Wild citrus species

*Timber business was very high till 1990s. Now timber extraction is banned by Honorable Supreme Court of India

${ }^{a}$ NTFPs (Non-timber forest products) are wild fruits, medicinal plants, leafy vegetables and wild tubers for rearing pig

${ }^{\mathrm{b}}$ Subsistence agriculture includes cultivation of rainfed paddy (high glutinous varieties preferred for food and preparing traditional alcoholic beverage- apong), mirung (finger millet), angyat (foxtail millet), 2 varieties of shapa (indigenous maize), pearl millet, sugarcane, 6-7 species of indigenous beans including namsing (soybean), cucurbit crops (3-4 species), 8-10 species of indigenous leafy vegetables, 2-3 species of tuber and 2-3 species of rhizomes

'Most potential micro-ecosystem for fishing of 6-7 species of indigenous fishes and other aquatic animals

${ }^{\mathrm{d}}$ This landscape is used for cultivating wetland paddy for food and sale in local markets by Adi women

${ }^{\mathrm{e} H o m e g a r d e n s}$ are considered as a life laboratory of learning traditional knowledge to Adi women, and significant component of integrated farming system after the regpi forest

foko-patta is taken as a living fence, and is a most popular multi-purpose tree species. In a few villages, community and individually owned gardens of toko-patta were recorded

ensure democratic, inclusive and informed decision-making; resolve disputes; and sustain forest resources through the village Kebang (see Singh et al. 2015 for structure and functioning of the Kebang). As noted previously, disputes over forest land use are filed in the village Kebang before GB by the Co-GB (Fig. 2a). Opposing claimants are given ample time to produce evidence to support their claims. The GB hears the case and takes the final decision after considering the elders' opinion. In certain cases, such disputes are resolved in Bango Kebang or Bagung Bokang (higher and supreme courts, second and third tier of the Kebang). When disputes on forest use occur between two different villages of the same community, but from different ecological edges, then GBs of both the villages call a meeting to hear the case at the village boundary. In the early days, such meetings were usually held at the village dividing riverbank. To ensure justice in forest disputes, both claimants have to take oath of tiger and snakes from their respective community forests. 
Table 2 Qualitative assessment of diverse values of varied local forests as perceived by the Adi tribe

\begin{tabular}{|c|c|c|c|c|c|c|c|c|c|c|c|}
\hline \multirow[t]{2}{*}{ Forest typology } & \multicolumn{2}{|c|}{ Subsistence value $e^{1,+1}$} & \multicolumn{2}{|c|}{ Economic value $e^{1,+2}$} & \multicolumn{2}{|c|}{ Cultural value $e^{1,+3}$} & \multicolumn{2}{|c|}{ Ecological value $e^{1,+4}$} & \multirow{2}{*}{$\begin{array}{l}\text { Sum of } \\
\text { ranks }\end{array}$} & \multirow{2}{*}{$\begin{array}{l}\text { Rank } \\
\text { of sum }\end{array}$} & \multirow{2}{*}{$\begin{array}{l}\text { Indicative indicators } \\
\text { for valuation }{ }^{2}\end{array}$} \\
\hline & Score & Rank & Score & Rank & Score & Rank & Score & Rank & & & \\
\hline Morang & 10 & I & 6 & V & 10 & । & 10 & I & 8 & I & 1 \\
\hline Regpi & 9 & $\|$ & 8 & III & 9 & $\|$ & 9 & $\|$ & 9 & $\|$ & 2 \\
\hline Monku & 4 & VII & 7 & IV & 6 & V & 7 & IV & 20 & VII & 3 \\
\hline Mosam & 7 & IV & 8 & III & 8 & III & 8 & III & 13 & IV & 4 \\
\hline Sirung & 7 & IV & 6 & V & 7 & IV & 8 & III & 16 & V & 5 \\
\hline Homegardens & 8 & III & 8 & III & 7 & IV & 9 & $\|$ & 12 & III & 6 \\
\hline Orange garden & 6 & V & 10 & । & 5 & $\mathrm{Vl}$ & 5 & $\mathrm{Vl}$ & 18 & $\mathrm{Vl}$ & 7 \\
\hline Pineapple gardens & 5 & $\mathrm{Vl}$ & 9 & $\|$ & 4 & VII & 5 & $\mathrm{VI}$ & 21 & VIII & 8 \\
\hline Traditional tea-garden & 8 & III & 7 & IV & 5 & $\mathrm{Vl}$ & 6 & V & 18 & $\mathrm{Vl}$ & 9 \\
\hline Village boundary forests & 4 & VII & 3 & $\mathrm{Vl}$ & 6 & V & 7 & IV & 22 & IX & 10 \\
\hline
\end{tabular}

The scoring was done on 1 to 10 scale on consensus basis applying FGD (focus group discussions) with key knowledge holders (average 12 member) on four parameters (subsistence to ecological values) against a particular forest typology

${ }^{1}$ The scoring of value of a particular parameter was based a range of biophysical, cultural and other indicators

${ }^{2}$ The list of indicative indicators thematically patternized (Braun and Clarke 2006; Stringer et al. 2017) to assign the scores as provided in Additional file 1: Table S.5 in S1

${ }^{+1} \mathrm{~A}$ forest which is often used in both normal and abnormal conditions for survival

${ }^{+2}$ When a particular forest is accessed for collection of species (plant and animals) specially for market sale

${ }^{+3}$ When a forest is accessed more for fulfilling needs of hunting, fishing, spiritual acts, accessing to meet needs of special foods, etc.

${ }^{+4}$ When a forest components (plant, animals, soil, water, etc.) are treated to play critical roles in conservation of not only biodiversity, but also maintaining tangible and non-tangible ecosystem services (e.g., water for irrigation and drinking, maintain endangered and rare species)

The meeting of the Bango Kebang or Bogung Bokang is held in a dere (in Miyong sub-tribe of Adi) or musup (in Pasi and Padam sub-tribes), specially designed huts made of toko-patta leaves and bamboo stems. Case hearing and resolution can sometimes take more than 3 days. During the hearings, food materials accessed from the forest are cooked on the spot. Making the hut and organizing the meeting on the main site result from the belief that the hilly edges and forests have spiritual power and that no Adi would dare to lie during the meeting. Bango Kebang and Bogung Bokang juries take rational decisions acceptable to both the parties.

Morang forests are demarcated by village Kebang by using natural ecological edges and stones to avoid possible conflicts between the two communities. It is expected that neighboring community will honour the demarcated boundaries and will not enter into others' territory for hunting or harvesting

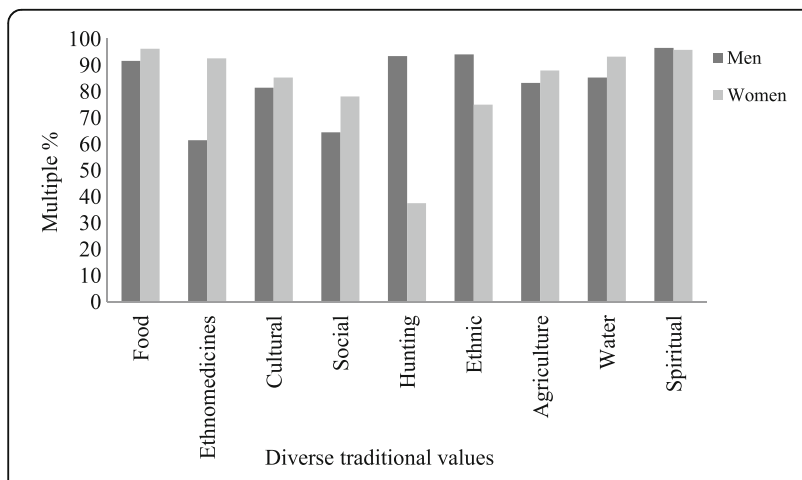

Fig. 1 Diverse values of morang forest as perceived by Adi folks forest products. Until the 1970s, the entire morang forest was under the control of Kebang-access to and use of forest land was approved in advance by the Kebang. However, with the passage of time and the accompanying demographic and socio-political changes, individual ownership of morang gradually came into being. Nevertheless, Kebang still enjoys considerable rights over morang, especially in relation to conflict resolution.

Norms set by the village Kebang and overseen by the GB help prevent the overexploitation of forest biodiversity and that of rivers and streams originating from the forests. Recently, fishing in rivers was banned by the GBs of a few Adi villages to arrest declining populations of small local fish (ngopi, gari, ngori, ngope, orpu, tapo, etc.) and the resulting conflicts among Adi fishermen. Currently, only controlled fishing is allowed considering the main breeding season and type of fishing gear employed. Fishermen are required to obtain verbal permission from the GB. Permission is granted on the condition that only traditional fishing equipment such as edil and porang (made of local bamboo), and nets (sabjung-made of a forest creeper called ripum) with a defined mesh size (3-in.) will be used. Fishermen are prohibited from using any poisonous plants, such as onger and marshang (Spilanthes acmella) for fishing. If someone is caught fishing using modern but banned techniques like electric currents, lime, bombs and dynamite, a fine of INR. 5000 to 20,000 is imposed. A committee constituted by the Kebang conducts random checks to ensure sustainable fish catch.

Women are also active participants in conserving and sustaining local biodiversity through their own informal 


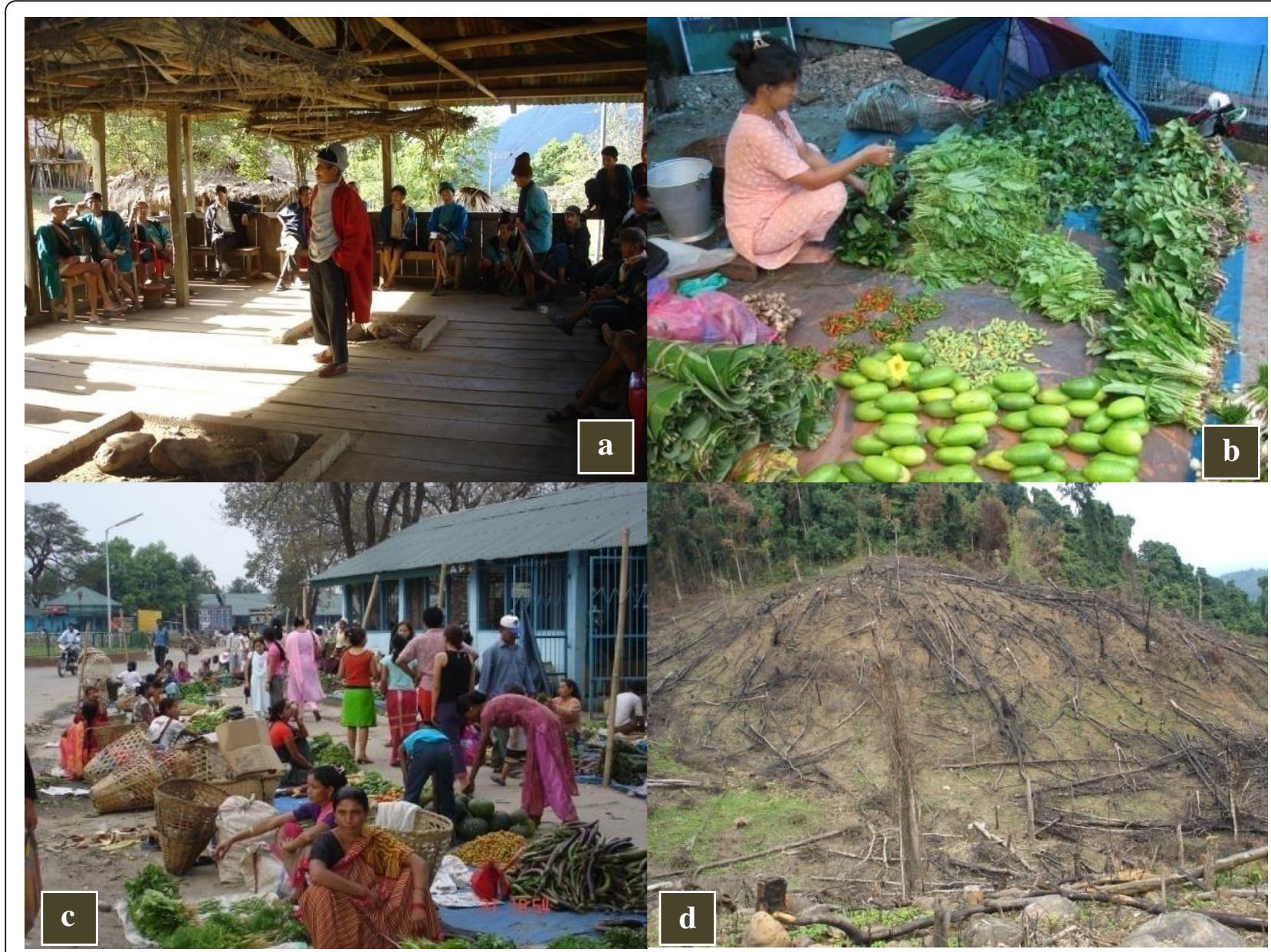

Fig. 2 a A village Kelang going on to solve the dispute over regpi forest between two claimants of same village. b, c Adi women selling indigenous leafy vegetables and other products harvested from regpi forest and home garden. $\mathbf{d}$ A regpi forest cleared and burned for establishing an orange garden

institutions like rilam (among Minyong ethnic group) and reglep (among Pasi) for help in collecting firewood and accessing indigenous vegetables (ongen, onger, oyik, tapar, mushrooms, bamboo shoots, etc.) from the forests in groups. This approach helps reduce the drudgery and time, and to ensure that a particular plant resource is not overexploited. Violation of ethical norms set by these institutions invites criticism and in severe cases, imposition of fines by the village Kebang.

\section{Access of community forests: interactions of ecosystem services and socio-cultural capital}

Hunting and access of food and ethno-medicinal resources

Hunting is an integral activity of the Adi tribe. During the 1950s, ownership over forest lands was decided through a lead hunting system, with an experienced designated hunter who set ecological boundaries with stone markers, and allotted a specific pocket to a particular hunter. Now, this tradition has changed with community-defined ecological boundary of a clan where they hunt wild games.
Adi people identify more than 25 aquatic and terrestrial animal species used in local food systems. These include mongoose, squirrels, rats, monkeys, ringtails, grasshoppers, red ants, snails, shrimp, crabs, prawns, porcupines, pigs, male buffalo, mithun, forest cats, fish, snakes and various other reptiles. Hunting of larger forest animals is done by men, while insects, shrimps and prawns are generally collected by women. Wild animals are consumed in different forms along with various plant-based foods. Until 1980s, these animals and aquatic resources were hunted and caught using manual tools and practices applying local plant materials. Harvesting was done carefully for maintaining forest biodiversity. Nowadays, however, younger generation uses air-guns and pistols to hunt wild game threatening the wildlife.

Adi community has developed a holistic view of local ecosystems where living and non-living components form an inseparable whole. One of the woman knowledge holders narrated that: 
Every plant, animal, stone and river has a soul and it sounds, you should be able to listen them, and care respectfully.

Such philosophy of life among Adi has evolved a sense of sustainably utilizing the land and forest resources, thus creating rich spirituals and norms to regulate behaviour in relation to managing natural resources. To signify this philosophy in relation to using and clearing the lands for jhum and forest for hunting, further two knowledge holders narrated it with following folktale:

Sikking Kemom Mapun-yamo

Taglek E Taglikdak

Means $\mathrm{O}$ forest and mountain god and goddess, I am in a need of my survival and want your consent to use this piece of land/forest. I am not claiming this land/ forest of mine property, rather I need it on your mercy only for certain years.

Adis celebrate various festivals for sustainable forest and other natural resources management. They go hunting individually or in groups (for details, see Additional file 1: Table S.6 in S1). Aran and etar are two such group hunting festivals. Before hunting, they perform a ritual called Pombek Pomto as an offering to the forest deities for safe hunting. Hunters also wish to communicate to the deities that hunting will be done only after their consent. Other festivals including solung, kiiruk, koson, and folk dances called ponung and tapu are also interwoven with the use values and conservation of forest resources (details in Additional file 1: Table S.6 in S1). The knowledge of collecting forest resources and traditional food utilized during various hunting festivals varies with the social system (transitional and traditional), as well as age, gender and underlying cultural beliefs. For example, if a woman is pregnant, then her husband should not dig the soil or hunt any monkey (detailed beliefs described in Additional file 1: Table S.6 in S1). However, celebration of festivals with rituals and cultural activities has now undergone some changes, and variations were found between transitional and remote villages.

The Adi tribal members living in remote villages have developed incremental learning over a period of time in identifying forest plant species for use as food and ethnomedicine (Table 3). Some species are available only in particular months while others can be obtained year round in remote villages. These plants are well conserved in morang and regpi forests in remote villages, especially where exotic horticultural crops (orange, ginger and pineapple) have not been introduced. Economically poor women of remote villages collect and sell key plant resources directly in local markets to generate income (Fig. 2b, c), while those of transitional villages (closer to towns centres) often receive ethno-botanical products from their counterparts in remote regions.

\section{Stakeholders in forest resources' access and use}

Forest resource user Adi groups vary according to the nature of their roles and responsibilities (Table 4). While landowning Adi community has direct control over forest resources, non-tribal migrant dwellers (Nepalese, Assamese, Biharis and Marwadis) have only indirect beneficiaries of these resources. Elaborate interrelations between locals and external actors reveal the complexity of learning and mediations for sustainable conservation and livelihoods (Fig. 3) influencing not only the sustainability of forest resources but also the learning of local biodiversity stewardship.

\section{Overall ecosystem services from community forests}

Insights gained during the valuation of forest typology triggered a deeper analysis to assess the respondents' perceptions about provisioning, cultural, regulatory and supporting services availed by the Adis from locally classified forests. Results revealed that bamboo, local crops, ethnic vegetables, ethno-medicine, fish and other aquatic animals, fodder, fuel wood, grass, gravels, land, fuel wood, timber and water are the major provisioning services provided by community forest. Most of these are treated as 'most important' (41 to 95\% perception responses) on the importance scale of ecosystem services (Table 5). Places for hunting (91\% response) and celebrating festivals (66\% response) and aesthetic values for attracting ecotourism (61\% response) were found as most important cultural services of locally classified community forest. Adi community perceived that control of soil erosion and landslides (75.0\% response), flood control (70\% response), improved soil fertility in jhum lands (81\% response) and maintaining micro-ecosystem [(for conserving valuable plant and animal species, and moderation of drought and extended dry-spell impacts) (69\% response)] are the major regulatory and supporting ecosystem services of the community forests.

Traditional Adi men and women access different ecosystem services, such as in provisioning (certain locally available plants used in food and medicines) on a particular day, time and season, according to their belief system. Sun and moon are considered important spiritual deities prayed during harvesting of forest resources, and while implementing soil and land management practices. After sunset and on full moon days, Adi refrain from harvesting ethnomedicinal plants. A strong majority of Adi members (78\% males and $85 \%$ females) perceived that socioeconomic changes and modernization have 
Table 3 Use of major ethnobotanicals by Adi community in remote locations to sustain life

\begin{tabular}{|c|c|c|c|c|c|}
\hline Local name & Botanical name & Seasonal availability & Purpose & $\begin{array}{l}\text { Availability in } \\
\text { forest typology }\end{array}$ & Part used \\
\hline$\overline{\text { Adi litchi }}$ & Nephelium lappaceum & May-June & Fruit & $M G, M K$ & Fruit \\
\hline Akshap & Mussenda roxburghii & Year round & Vegetable and medicine for diabetes & $\mathrm{R}, \mathrm{HG}, \mathrm{PG}$ & Leaf \\
\hline Anke & Aesculus assamica & September-October & Food during drought & MG, MK & Seed \\
\hline Bamboo tenga & Bambusaarundinacea & May to September & Food & $\mathrm{R}, \mathrm{MG}, \mathrm{MK}$ & Stem \\
\hline Bangko & Solanum spirale & Year round & Food & Mo, R, HG & Leaf \\
\hline Belang & Artocarpus heterophyl-lus & June-July & Fruit (earlier used as drought food) & Mo, MG, MK & Seed \\
\hline Ddony gori & Cassia tora & May August & $\begin{array}{l}\text { Vegetable and medicine in } \\
\text { skin diseases, and as soil mulch }\end{array}$ & $\mathrm{R}$ & $\begin{array}{l}\text { Leaf \& } \\
\text { seed }\end{array}$ \\
\hline Dhenkia saag & Diplazium esculentum & $\begin{array}{l}\text { April to June and } \\
\text { September-October }\end{array}$ & Vegetable specially during flood & $M o, R, H G$ & Leaf \\
\hline Dipo talo & Tepustria aurantiaca & May to September & Used in fishing & Mo, R, HG & Leaf \\
\hline Era-paat & Ricinus communis & October to December & Used in skin diseases & $\mathrm{R}, \mathrm{Mo}$ & Leaf \\
\hline Hevali & Nyctanthes arbor-tristis & April to August & Used in stomach disorders & $\mathrm{R}, \mathrm{HG}$ & Leaf \\
\hline Hilika & Terminallia chebula & October to December & $\begin{array}{l}\text { Used in reducing blood sugar, } \\
\text { stomach disorders }\end{array}$ & $M G, M K$ & Fruit \\
\hline Kopi & Solanum viarum & May to September & As vegetable and in stomach disorders & $\mathrm{R}, \mathrm{HG}, \mathrm{Mo}$ & Fruit \\
\hline Koppir & Solanum xanthocarpum & May to September & As vegetable and in stomach disorders & $R, H G, P G, M o$ & Fruit \\
\hline Kordoi & Averrhoa carambola & October December & Used in treating jaundice & $\mathrm{R}, \mathrm{HG}, \mathrm{PG}$ & Fruit \\
\hline Jojing balang & Physalis minima & May to August & Used as vegetable & $R, M G$ & Leaf \\
\hline Marsang & Spilanthes paniculata & May to September & Used as vegetable and in fishing & $R, P G$ & Leaf \\
\hline Morshi & Piper mullesua & April to September & Used as vegetable & $\mathrm{R}, \mathrm{HG}$ & Leaf \\
\hline Namdung & Perilla ocymoides & February to March & $\begin{array}{l}\text { Used as fermented food and chutney, } \\
\text { given to pregnant women for Mg and Ca }\end{array}$ & $\mathrm{R}, \mathrm{HG}$ & Seed \\
\hline Namiperi & Artemisia nilagarica & April to September & Used in cut and wound & $\mathrm{R}$ & Leaf \\
\hline $\begin{array}{l}\text { Nayang/oko-bodo/ } \\
\text { nami-pasi }\end{array}$ & Erigeron canadensis & May to August & Used as fragrant in fishes & $\mathrm{R}, \mathrm{HG}$ & Leaf \\
\hline Ogjok & Bahunia variegata & April to July & Used as vegetable & $H G, R, P G$ & Leaf \\
\hline Ombeng & Xanthoxylum nitidum & Year round & Food and medicine in high blood pressure & $\mathrm{R}, \mathrm{HG}$ & Fruit \\
\hline Onger & Xanthoxylum rhetsa & Year round & $\begin{array}{l}\text { Food and medicine in high blood pressure } \\
\text { and stomach disorders }\end{array}$ & $\mathrm{R}, \mathrm{HG}, \mathrm{PG}, \mathrm{TTG}$ & Leaf \\
\hline Ongin & $\begin{array}{l}\text { Clerodendrum colebrookianum } \\
\text { Linn. }\end{array}$ & Year round & Used as vegetable and in diabetes & $R, H G, P G$ & Leaf \\
\hline $\begin{array}{l}\text { Ori, Sayong/ } \\
\text { kebu Nanung }\end{array}$ & Polygonum sp & Year round & Used as vegetable & $\mathrm{R}, \mathrm{HG}$ & Leaf \\
\hline Oyik & Pouzolzia benettiana & May to August & Used as vegetable & $H G, R$ & Leaf \\
\hline Paput & Gnepalium affine & & & $H G, R$ & Leaf \\
\hline Pettu & Brassica sp. & May to August & Used as vegetable for new mothers & $\mathrm{R}, \mathrm{HG}$ & Leaf \\
\hline Rukdik & Amphineuron opulatum & May to August & $\begin{array}{l}\text { Used in cut, wound and skin diseases, } \\
\text { fish poison }\end{array}$ & $\mathrm{R}, \mathrm{HG}$ & Leaf \\
\hline Sajna & Moringa oleifera & March to May & $\begin{array}{l}\text { Used as vegetables and given to pregnant } \\
\text { women and new mother }\end{array}$ & $\mathrm{R}, \mathrm{HG}$ & $\begin{array}{l}\text { Fruit } \\
\text { and leaf }\end{array}$ \\
\hline Singlum & Callophyllum resintfertum & May to August & Sap is used for fragrance & $\mathrm{R}$ & Leaf \\
\hline Takeng & Zingiber spp. Linn & October to April & Used as spices and curing cough and cold & $\mathrm{R}, \mathrm{HG}$ & Rhizome \\
\hline Tapy & Gymnostema pedata & May to September & Used in skin stomach disorders & $R, H G, P G$ & Leaf \\
\hline Thniglung & Mitragyna rotundifolia Roxb & May to August & Used in skin diseases & $R, H G$ & Leaf \\
\hline
\end{tabular}


Table 3 Use of major ethnobotanicals by Adi community in remote locations to sustain life (Continued)

\begin{tabular}{|c|c|c|c|c|c|}
\hline Local name & Botanical name & Seasonal availability & Purpose & $\begin{array}{l}\text { Availability in } \\
\text { forest typology }\end{array}$ & Part used \\
\hline Yelong & Polygonatum multiflorum & May to September & Used in fever & $R, H G, P G$ & Leaf \\
\hline Yikro & Urticaceae family plant & May to September & Used in fever & $\mathrm{R}$ & Leaf \\
\hline Yocle & Plectrarphos japarca & May to August & & $\mathrm{R}$ & Leaf \\
\hline
\end{tabular}

Source: Own analysis. MG Morang, MK Monku, Mo Mosam, R Regpi, HG Homegarden, PG Pineapple garden, TTG Traditional tea garden

affected the continuance of Adi belief system, and thus adversely affecting conservation of local plants as evidenced by the declining populations of Gymnocladus burmanicus, Coptis teeta, Begonia aborensis and Begonia scintillans in local forests.

\section{Discussion}

The importance and role of traditional ecological knowledge (TEK) and indigenous institutions in classifying and managing native forests is well recognized globally (Balee 1994; Shepard et al. 2001). As our results revealed, 15 criteria used by Adi people in classifying local forests indeed reflect the complexity of knowledge interactions with forest ecosystems, and their potential implications. Adi's forest classification system is affected by many indicators: ecological, institutional, socioeconomic and cultural, as previously reported by Sangha and Jalota (2005) and Dai et al. (2017). The degree of inter-relations among such indicators might shape the perception of local people to value or not a particular forest for its tangible and non-tangible services, and accordingly devise the criteria to classify and manage the associated resources. The location-specific survival strategies, particularly in forest-rich ecosystems, often compel the local communities like Adi to evolve their nature centric behaviour making them different from others living in settled environments on account of unique TEK and subsistence livelihood styles (Gadgil et al. 2000; Orchard et al. 2016). Intricate relations among such local indicators have been found to be the key factors sustaining community forests and related ecosystem services across the world (Parrotta and Trosper 2012). Available evidence suggests that tribal and Indigenous people have played critical roles in conserving the biodiversity using TEK and institutions (Gadgil et al. 2000; Lahiri 2017). Adi village Kebang, by effectively conserving important habitats and plant species through TEK and indigenous institutions, has contributed immensely to livelihood security (Agrawal and Chhatre 2011; Lahiri 2017).

We recorded multiple outcomes of community-based forest resources in terms of provisioning, supportive, regulatory and cultural services intrinsic to the well-being and identity of a traditional community. In this study, partial differences in perceptions of Adi with regard to the relative importance of a particular ecosystem service (Table 5) are consistent with the observations of Pirard et al. (2017) and can be explained by the strong interconnections between food habits, culture and forest resources (Díaz et al. 2011). Further, collectively managed and least disturbed forest types, morang, regpi, and mosam (in decreasing order), were found to be rich in such services as previously reported by Dai et al. (2017). Communities like Adi inhabiting fragile ecosystems have developed a cohesive bond with such collectively managed forests and the associated ecosystem services than privately owned resources (e.g. orange and pineapple gardens) due to least availability of external resources to sustain their livelihoods (APHDR 2005). Differences between formal and informal ways of classifying and managing forests have always been undervalued by the state policy makers of Ar P (Ramakrishnan 2002, 2005), a concern also pointed out by Shrestha et al. (2010). Despite several policy initiatives, jhum cultivation continues unabated in many parts of northeastern India (Ramakrishnan 2002, 2007) dealing a severe blow to local biodiversity and other natural resources. Local people have shown a positive response to some of the policies, like those relating to the integration of legume crops and

Table 4 Stakeholders' rights and responsibility in relation to the forest resources

\begin{tabular}{|c|c|c|}
\hline Stakeholders & Rights & Responsibilities \\
\hline Animal owner & $\begin{array}{l}\text { Can make the cattle a source of income } \\
\text { and rituals use }\end{array}$ & Look carefully the cattle, not to destroy others field \\
\hline Forest land owner & $\begin{array}{l}\text { Can use the forest products by his } \\
\text { own wish }\end{array}$ & $\begin{array}{l}\text { Monitor the forest land and check the movement } \\
\text { from outsiders }\end{array}$ \\
\hline Gaon Burha & $\begin{array}{l}\text { To make the law and order for welfare } \\
\text { of the community }\end{array}$ & $\begin{array}{l}\text { To deal and manage over the disputes among the } \\
\text { community and village }\end{array}$ \\
\hline Village Priest & $\begin{array}{l}\text { Cultural rights to ask Gaon Burhas } \\
\text { for providing forest products }\end{array}$ & $\begin{array}{l}\text { To look after the festivals, occasion and other evil } \\
\text { happening to the village and performing rituals }\end{array}$ \\
\hline
\end{tabular}




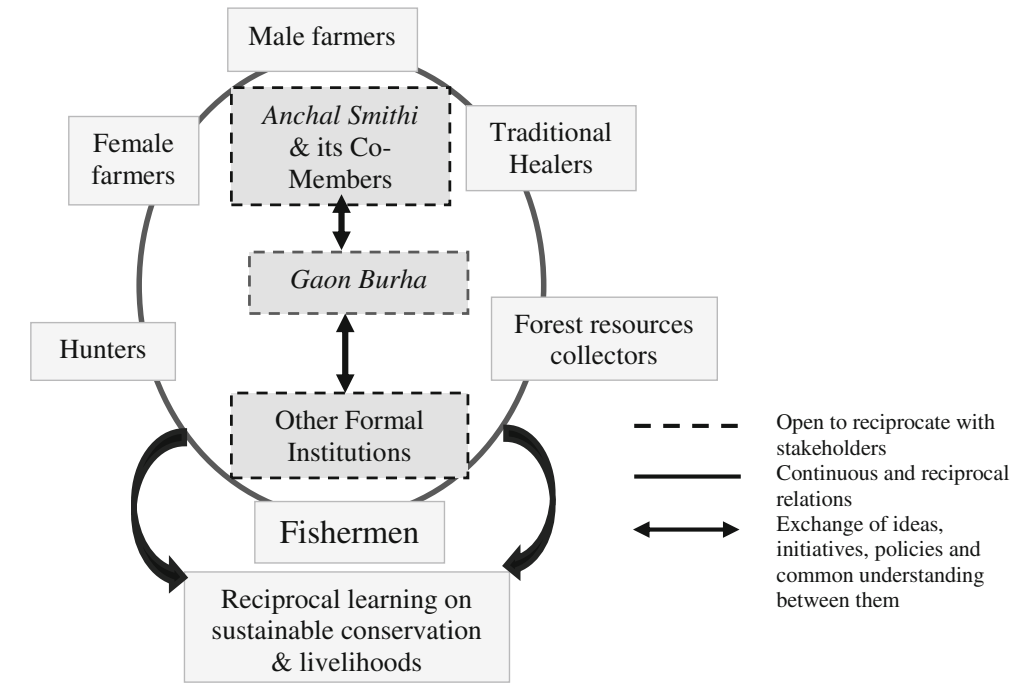

Fig. 3 A thematic diagram showing interrelations of multiple stakeholders in sustainable conservation of forest biodiversity

trees in the existing agroforestry systems, and soil and water conservation measures, but only after reconciling these with their TEK (Ramakrishnan 2005). Contrary to this, government incentives and subsidized inputs for commercial horticultural production (especially in transitional villages) have increased the conversion of regpi forest lands (Fig. 2d) into orange and pineapple gardens adversely impacting availability of and access to forest-associated ecosystem services. Jhum cultivation is believed to have destroyed $\sim 12 \%$ of the global tropical forests, and destructive impacts are usually very high when jhum fallow period is reduced to 2-4 years (Singh et al. 2014). Uncontrolled logging also erodes an equal percentage of local community-managed forests (Hamilton and Hamilton 2006).

A well-thought out blend of local harvesting strategies is considered a prerequisite to maintain sustainability of the local resources (Turner and Berkes 2006). Adi follow different modes and gender-based harvest strategies for accessing indigenous biodiversity (Table 6). For example, during group harvesting in morang forests, each harvester is closely watched by an elder so that he/she does not exceed the prescribed harvest limit. Such sustainable harvest strategies followed by Adi are yet not integrated in 'bottom to top' policies on forest resources for sustainable outcomes (Ramakrishnan et al. 1996). Different stakeholders involved in forest resources access and use may vary in terms of their TEK and responsibilities of forest management and therefore may ultimately affect the sustainability of forest resources and associated services. Often, it might happen that knowledge of one stakeholder about forest resources (such as of a particular plant or animal species) may not be known to others (Keen et al. 2005; Sterling et al. 2017) jeopardizing the community plans and initiatives for sustainable conservation (Brown et al. 2013). We found that while Adi hunters rate the leguminous tree Gymnocladus burmanicus to be less abundant than before in regpi and morang forests, other user groups had little knowledge about this species. Since hunters construct their hunting points around this tree (dropped off fruits serve as bait to deer and boar), they are well familiar with this species. Similarly, Adi women had better knowledge about the population status, time of movement and habitat of tari insect (Aspongopus najus) used as food (Singh et al. 2015a, 2015b). These examples, reflecting the specific knowledge of a particular social group can play an important role in sustainable forest resource management (Agrawal and Chhatre 2011). However, State Forest Department has only occasionally harnessed these insights in developing and implementing community-based forest planning and conservation programmes (Ramakrishnan 2007). Participation of different stakeholders seems necessary for reciprocity and exchange of knowledge, and trust building to enhance the biodiversity conservation and livelihood options (Garnett et al. 2007; Sterling et al. 2017), as well illustrated in Nepal (Shrestha et al. 2010) and with Indigenous People (UN 2014).

Villages GBs have sufficient control over community forest resources. Over $95 \%$ of the GBs agreed to share their community's TEK and institutional support in managing state forest resources sustainably. They were even ready to lease out certain morang groves to the interested state agencies for a specific period of time for research on conservation, and mitigation and adaptation that could directly contribute to State's Action Plan on Climate Change [(reducing emissions from deforestation and forest degradation, and forest conservation) 
Table 5 Major ecosystem services from community forests perceived as important by the Adi community

\begin{tabular}{|c|c|c|c|}
\hline \multirow[t]{2}{*}{ Ecosystem services and resources } & \multicolumn{3}{|c|}{ Multiple $\%^{a}$} \\
\hline & Most important & Important & Least important \\
\hline \multicolumn{4}{|l|}{ 1. Provisioning services } \\
\hline Bamboo/toko leaves (multiple use such as fencing, income, constructions, etc.) & 75.56 & 20.65 & 6.60 \\
\hline Ethnic foods (vegetables, insects and wild games) & 75.34 & 24.66 & 2.23 \\
\hline Ethnomedicines & 85.89 & 14.11 & 2.40 \\
\hline Fish and other aquatic animals (from ecological edges of forest steams) & 67.56 & 30.89 & 1.55 \\
\hline Fodder & 67.89 & 20.65 & 8.95 \\
\hline Fuel wood & 80.35 & 15.45 & 7.56 \\
\hline Grass (for thatching) & 68.90 & 20.15 & 7.64 \\
\hline Gravels for road and other constructions & 40.98 & 35.67 & 17.54 \\
\hline Land for housing and fields & 79.45 & 18.45 & 5.4 \\
\hline Poles (used for house constructions) & 82.60 & 18.90 & 4.34 \\
\hline Reeds (used in mats) & 45.67 & 38.98 & 13.54 \\
\hline Rope (multipurpose use) & 50.50 & 40.98 & 8.52 \\
\hline Timber (for house and local sale) & 70.45 & 25.43 & 4.12 \\
\hline Water (for irrigation, and drinking) & 95.00 & 00.00 & 1.12 \\
\hline Wood (used in making implements, etc.) & 55.46 & 35.78 & 9.43 \\
\hline \multicolumn{4}{|l|}{ 2. Cultural services } \\
\hline Aesthetic value (now eco-tourism is increasing) & 60.50 & 15.0 & 00.0 \\
\hline Place for celebrating indigenous festivals & 65.98 & 20.45 & 9.43 \\
\hline Place for hunting & 90.55 & 09.45 & 3.30 \\
\hline \multicolumn{4}{|l|}{ 3.Regulatory and supporting services } \\
\hline Control of soil erosion/land slides & 75.0 & 25.0 & 00.0 \\
\hline Flood control (intense and torrential rains) & 70.0 & 30.0 & 00.0 \\
\hline Leaf litters for soil fertility, and soil availability for jhum crops & 80.55 & 19.45 & 2.12 \\
\hline $\begin{array}{l}\text { Maintaining micro-ecosystem (to conserve valuable plant and animal species, } \\
\text { and moderation of drought \& extended dry-spell }\end{array}$ & 69.70 & 27.89 & 2.41 \\
\hline
\end{tabular}

Source: Own analysis. Based on the pooled data of men and women

${ }^{a}$ Due to multiple responses pooled from male and female Adi members, the total of individual items will not add up to 100

$\left(\mathrm{REDD}^{+}\right)$] (GoArP 2011), provided there are opportunities for the equitable sharing of supposed benefits (Singh and Padung 2010). It is therefore desirable that such experienced individuals with their rich socio-cultural capital and knowledge networks are included in the future conservation programmes (cf: Pretty and Smith 2004) similar to the policy on sustainable Himalayan ecosystems initiative (NAPCC 2008).

Agricultural and food systems in Ar P are governed mainly by women who remain engaged in collecting, processing and managing forest and other natural resources (Mishra et al. 2011). The unparalleled role of Adi women in sustaining indigenous agro-biodiversity could be a great source of inspiration for conservation scholars and policymakers. Adi women play a pivotal role through their traditional practices (e.g. seed preservation, species domestication and modification of micro-ecosystems) essential to sustaining the plant resources (Fig. 4). We found that these traditional practices were more prominent in regpi forests followed by homegardens and morang forests. Women's creativity and their informal institutions are location specific and play horizontal as well as vertical roles through their knowledge systems and barter networks. Such networks not only help enhance knowledge learning and conservation practices in maintaining ecosystem services but also contribute to enhancing ecosystem resilience. In contrast to the female indigenous peoples recognized for their wisdom elsewhere (Anderson 2005; Turner 2005; Turner and Clifton 2009), the significant roles of Adi women continue to be ignored in the biodiversity conservation measures in the study region.

\section{Conclusions}

This study concluded how Adi people classify the local forests into different types using ecological, social, cultural and apparent livelihood indicators. Our study confirmed 
Table 6 Access and harvesting strategies used by Adi tribe

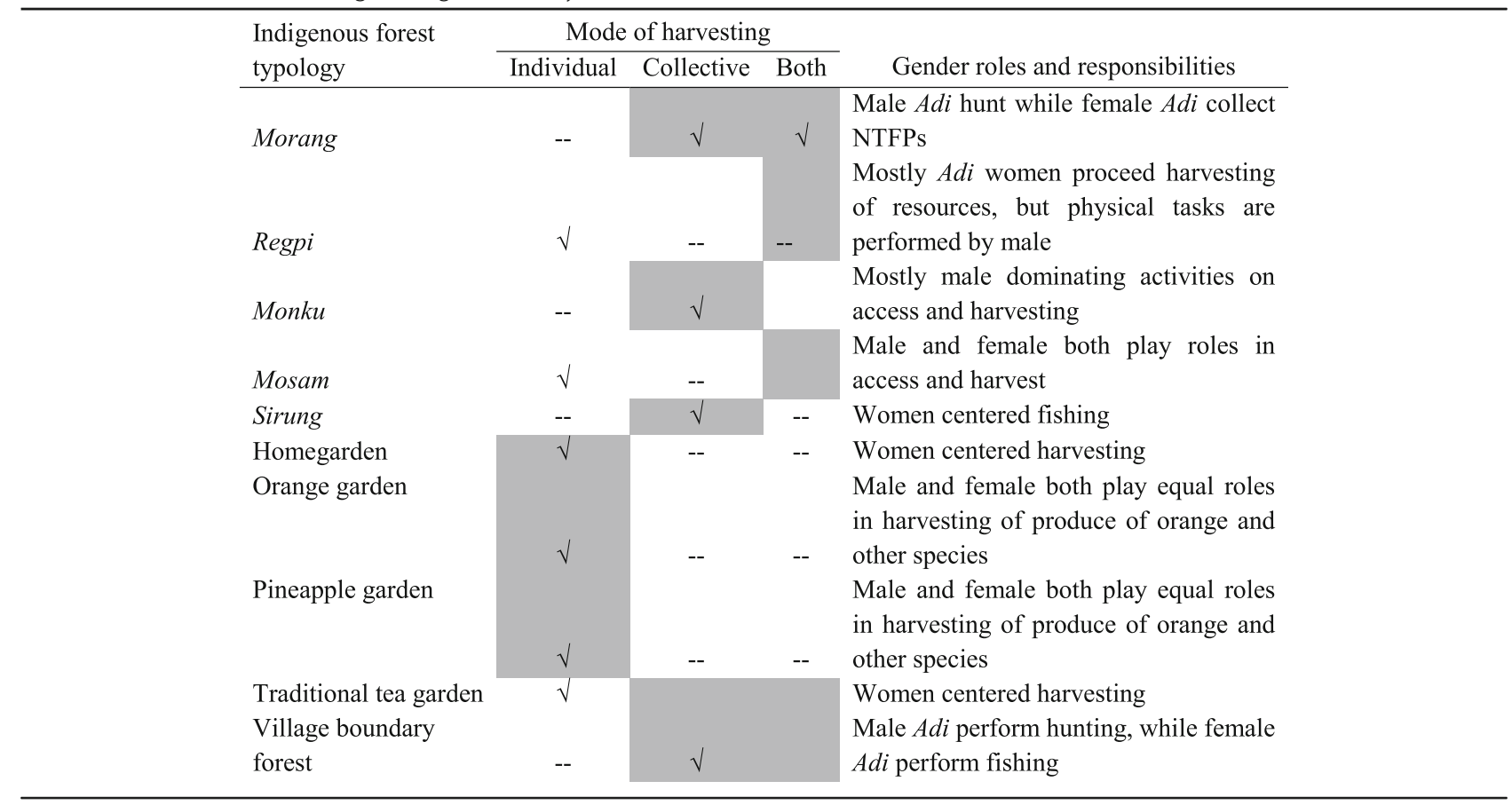

Source: Own analysis

that indicators used in classifying community forest are comprehensive and broadly supported by traditional ecological knowledge (TEK) and determine the access of forest resources. While some locally classified forests have a higher subsistence value (morang), others are important from agricultural (regpi), economic (orange and pineapple gardens) and cultural (hunting and festivals) perspectives. While Adi adjudged morang, regpi and monku forest types to be the most valuable, others were not underrated. Community forests provide an array of provisioning, cultural, regulating and supporting ecosystem services perceived to be critical to the well-being of Adi community.

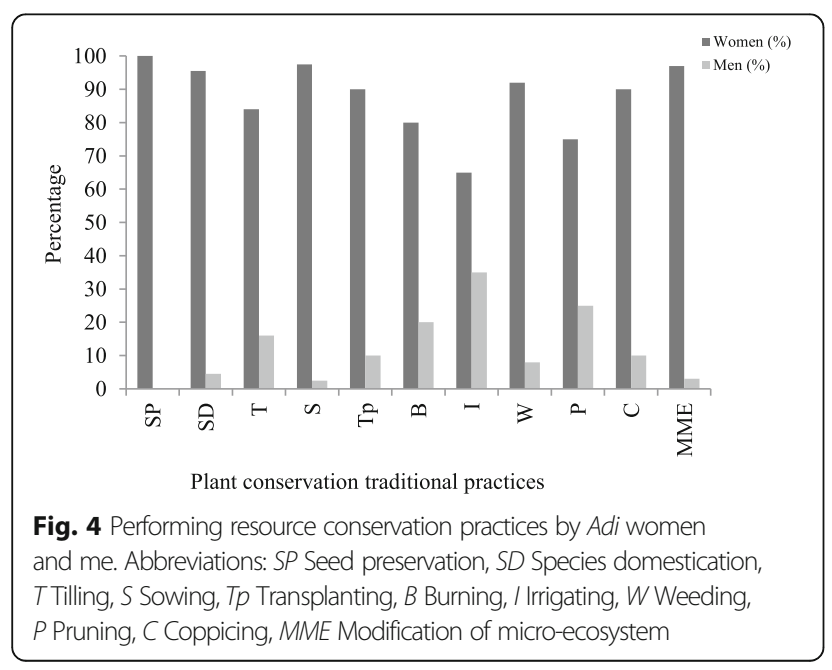

Strategies of harvesting the forest resources using time-tested TEK and supported by social norms ensure the sustainable management. The Adi's system of forest classification provides insights for developing more sustainable ways of knowing and managing communitybased forest resources not only in Arunachal Pradesh but also in other parts of the world having similar resources and constraints. Understanding the range of variation between remote and transitional social-ecological systems may make major difference in enhancing our knowledge and institutions relating to biocultural resource use, and management systems. The TEK-led system of forest classification developed by Adi tribe may find compatibility with concept of knowledge co-production and co-management of forest resources and conservation of biodiversity along with enhancing ecosystem services in Ar P and in similar other regions. The social-ecological system of this state is very different from other parts of India, and it needs a place-based perspectives. A few suggestions for researchers and policy makers are:

Adi's traditional knowledge and forest classification system supported by advanced tools like global positioning system and satellite imageries can be immensely useful to the future researches on sustainable ecosystem management in the northeastern region of India in general and Arunachal Pradesh in particular.

Community knowledge, with emphasis on social institutions, and village Gaon Burha and elders, needs to be utilized by the State Government in the 
development and implementation of forest conservation programmes.

Incorporation of traditional ecological knowledge and sustainable practices can substantially contribute to State's Action Plan on Climate Change (REDD ${ }^{+}$) and sustainable Himalayan ecosystem initiative.

Women's creativity and wisdom, and their informal social networks should be given due credit and place in programmes and policies on forest management in general, and those relating to ecosystem resilience in particular.

\section{Additional file}

Additional file 1: Approaches of sampling study respondents; details of steps and methodology in carrying out study; and additional results. (DOCX $44 \mathrm{~kb})$

\section{Abbreviations}

Ar. P: Arunachal Pradesh; Co-GB: Co-Gaon Burha (village level assistant customary chief); FGD: Focus group discussion; FSI: Forest Survey of India; GB: Gaon Burha (village level customary chief); JFM: Joint forest management; REDD ${ }^{+}$: Reducing emissions from deforestation and forest degradation, and forest conservation; TEK: Traditional ecological knowledge

\section{Acknowledgements}

The authors are grateful to all the Head Gaon Burhas, Co-Gaon Burhas and Adi community members who were part of this study, and others who have provided local supports and given the chance in their community to learn and record the data. Editorial contribution received from Professor Nancy J. Turner, University of Victoria, Canada, is appreciated. Suggestions received from two anonymous referees that improved the quality of paper are acknowledged. Logistic supports obtained from ICAR-Central Soil Salinity Research Institute, Karnal, India for preparing this article is appreciated.

\section{Funding}

All data collection, data analysis and write-up of the study were financially supported by the College of Horticulture and Forestry, Central Agricultural University, Pasighat, Arunachal Pradesh, India, through intra-mural research project and Rural Horticulture Work Experience (RHWE)

\section{Availability of data and materials}

Qualitative data for the paper were collected through personal interviews, FGDs, participant observations and informal interactions with community members. Substantial amounts of such data have been provided in online resources. However, corresponding author may be contacted in case of any clarifications.

\section{Authors' contributions}

RKS generated the idea and designed the study, collected and analyzed data and wrote the article. SMH and TR helped in refinement, supplementation and social validation of data. EP, OR and YJL were traditional knowledge holders from Adi community and provided all the local supports and expertise on the key terms and practices reported in this article. AS and AKB provided assistance in application of study framework and read and revised the manuscript. All the authors read and approved this manuscript.

\section{Authors' information}

Ranjay K. Singh is serving as Principal Scientist (Agricultural Extension) at ICAR-Central Soil Salinity Research Institute (CSSRI), Karnal, Haryana, India. His research interest includes human-environment interactions and has collaborated with tribal and marginal communities to work out local solutions for community-based natural resources conservation and adaptation to global environmental change. Shah M Hussain is a subject matter specialist in fishery sciences at Krishi Vigyan Kendra $(\mathrm{KVK})$, College of Horticulture and Forestry (CHF), Pasighat, Arunachal Pradesh, and works on the capacity building of farmers. T. Riba, having specialization in crop protection, currently works with KVK, CHF,
Pasighat in area of agriculture technology transfer. Anshuman Singh is working as Scientist at ICAR-CSSRI, Karnal, and has specialization in fruit crops. Egul Padung is the Principal at Doying Gumin College, Pasighat, East Siang, and has specialization in indigenous education systems. Mrs. Orik Rallen is a cultural food specialist and a conservator of culturally and medicinally valuable local plant species from East Siang district. Mrs. YJ Lego is a traditional herbal healer and an agricultural officer attached with the Department of Agriculture, Arunahcal Pradesh. Ajay Kumar Bhardwaj is a Senior Scientist (Soil Science) at ICAR-CSSRI, Karnal. His research interests include biogeochemistry of agroecosystems and ecological implication of intensive management systems.

\section{Ethics approval and consent to participate}

This is not applicable; however, the prior informed consent (PIC) was obtained in oral form from the studied respondents and community chief of sampled villages. This study does not need any formal approval.

\section{Consent for publication}

Not applicable.

\section{Competing interests}

The authors declare that they have no competing interests.

\section{Publisher's Note}

Springer Nature remains neutral with regard to jurisdictional claims in published maps and institutional affiliations.

\section{Author details}

${ }^{1}$ College of Horticulture and Forestry, Central Agricultural University, Pasighat, Arunachal Pradesh 791 102, India. ${ }^{2}$ ICAR-Central Soil Salinity Research Institute, Karnal, Haryana 132001, India. ${ }^{3}$ Doying Gumin College, East Siang, Pasighat, Arunachal Pradesh, India. ${ }^{4}$ Pasighat, India.

Received: 21 April 2018 Accepted: 20 June 2018

Published online: 16 July 2018

\section{References}

Agrawal A (2005) Environmentality: community, intimate government, and the making of environmental subjects in Kumaon, India. Curr Anthrop 46(2):161-190

Agrawal A, Chhatre A (2011) Against mono-consequentialism: multiple outcomes and their drivers in social-ecological systems. Glob Environ Chang 21:1-3

Agrawal A, Gibson CC (1999) Enchantment and disenchantment: the role of community in natural resource conservation. World Devel 27(4):629-649

Anderson MK (2005) Tending the wild: Native American knowledge and the management of California's natural resources. University of California Press, Berkeley $526 \mathrm{p}$

APHDR (2005) Arunachal Pradesh Hum Dev report. Department of Planning Government of Arunachal Pradesh, Itanagar: Arunachal Pradesh, India. pp. 110-120. file:///C:/Users/DR.\%20R.K\%20SINGH/Downloads/human_develop_ report_arunachal_pradesh_2005_full_report\%20(1).pdf. Accessed 3 June 2018

Balee W (1994) Footprint of the forest: Ka'apor ethnobotany-the historical ecology of plant utilization by an Amazonian people. California. University Press, New York

Berkes F (2002) Cross-scale institutional linkages: perspectives from the bottom up. In: Ostrom E, Dietz T, Dolsak N, Stern PC, Stonich S, Weber EU (eds) Drama of the commons. National Academy Press, Washington, DC, pp 293-321

Bisht RC (2008) International encyclopedia of Himalayas, Vol 3. Indian Himalaya. Mittal Publications, New Delhi, pp 29-60

Braun V, Clarke V (2006) Using thematic analysis in psychology. Qual Res Psychol, 3 (2). pp. 77-101. ISSN 1478-0887 Available from: http://eprints.uwe.ac.uk/ 11735. Accessed 15 Jan 2018

Brown C, Reyers B, Ingwall-King L, Mapendembe A, Nel J, O'Farrell P, Dixon M, Bowles-Newark NJ (2014) Measuring ecosystem services: guidance on developing ecosystem service indicators. UNEP-WCMC, Cambridge. https:// www.bipindicators.net/system/resources/files/000/000/436/original/1850_ESI_ Guidance_A4_WEB.pdf?1480342632. Accessed 1 June 2018

Brown E, Dudley NI, Lindhe A, Muhtaman DR, Stewart C, Synnott T (2013) Common guidance for the identification of High Conservation Values ( $\mathrm{HCV}$ ): a draft for consultation www.fsc.org/download.report-of-the-pc-reviewworkshop-of-the-25th-and-26th-of-june-2011.589. Accessed 8 Mar 2017 
Carlson TJS, Maffi L (2004) Introduction: ethnobotany and conservation of biocultural diversity. In: Carlson TJS, Maffi L (eds) Ethnobotany and conservation of biocultural diversity: advances in economic botany, vol 15. The New York Botanical Garden Press, Bronx, pp 1-6

CPS(2016) Religion data of census 2011: XXXII Arunachal Pradesh ST. http:// blog.cpsindia.org/2016/11/religion-data-of-census-2011-xxxii.html. Accessed 01-06-2018

Dai E, Xi W, Zhu J, Wang X, Dai E (2017) Quantifying ecosystem service trade-offs for plantation forest management to benefit provisioning and regulating services. Ecol Evol 7:7807-7821

Díaz S, Quétiera F, Cáceres DM, Trainor SF, Pérez-Harguindeguy N, Syndonia M, Bret-Harte Finegan B, Peña-Claros M, Poorter L (2011) Linking functional diversity and social actor strategies in a framework for interdisciplinary analysis of nature's benefits to society. PNAS 108(3):895-902

Elmqvist T, Berkes F, Folke C, Angelstam P, Crépin A, Niemelä J (2004) The dynamics of ecosystems, biodiversity management and social institutions at high northern latitudes. Ambio 33(6):350-355

FSI (2013) Indian State of Forest Report 2013. Forest survey of India. Available at: http://fsi.nic.in/cover_2013/sfr_forest_cover.pdf. Accessed 28 Sept 2017

Gadgil M, Achar KP, Bhat H, Bhat PR, Deshmukh S, Dolke A, Dolke Y, Vijay Edlabadkar N, Gogulwar S, Gokhale Y, Gunaga S, Gundappa BV, Heda N, Hiralal MH, Indiramma, Malhotra KC, Naik MB, Rekha GN, Pandharipande K, Patgar SG, Ramakrishnappa, Seshagiri Rao PR, Sivan W, Srinidhi S, Sujith S, Subramanian KA, Tofa D, Yetiraju (2005) People biodiversity register: a methodological manual. Centre for Ecological Sciences, Indian Institute of Science Bangalore 560012, India, pp 78

Gadgil M, Seshagiri Rao PR, Utkarsh G, Pramod P, Chatre A (2000) New meanings for old knowledge: the people's biodiversity registers programme. Ecolo Appl10:1251-1262

Garnett ST, Sayer J, Du Toit J (2007) Improving the effectiveness of interventions to balance conservation and development: a conceptua framework. Ecol Soc 12(1):2 http://www.ecologyandsociety.org/vol12/ iss1/art2/. Accessed 10 Oct 2017

GoArP (2011) Arunachal Pradesh state action plan on climate change. Government of Arunachal Pradesh, Itanagar, India. moef.nic.in/downloads/ public-information/Arunachal-Pradesh-SAPCC.pdf. Accessed 14 May 2017

Hamilton A, Hamilton P (2006) Plant conservation: an ecosystem approach. Earthscan, London

Huynh LTM, Stringer LC (2018) Multi-scale assessment of social vulnerability to climate change: an empirical study in coastal Vietnam Climate Risk Managhttps://doi.org/10.1016/j.crm.2018.02.003. Accessed 6 June 2018

Kaul RN, Haridasan K (1987) Forest types of Arunachal Pradesh: a preliminary study. J Econ Taxon Bot 9(2):379-389

Keen M, Brown V, Dyball R (2005) Social learning in environmental management. Towards and sustainable future. Earthscan, London

Khawas V (2003) Joint forest management in India with special reference to Darjeeling Himalaya. School of Planning, Center for Environmental Planning and Technology, Ahmedabad, India http://lib.icimod.org/record/ 11260/files/209.pdf. Accessed 30 June 2018.

Lahiri S (2017) Forest communities' struggle for traditional and customary use of forests in India. Forest Cover 53:13-16 https://globalforestcoalition.org/wpcontent/uploads/2017/11/forestcover-53-EN-low.pdf. Accessed 5 June 2018

Long CL, Zhou Y (2001) Indigenous community forest management of Jinuo people's swidden agroecosystems in southwest China. Biodivers Conserv 10:753-767

Mishra AK, Singh RK, Nachan SV, Singh R, Parat RK (2011) Enormity of indigenous knowledge systems for livelihood security in northeastern region of India: a case study. ICAR, Research Complex Barapani, Meghalaya

NAPCC (2008) National action plan and climate change of India. Prime Minister's Council on Climate Change, Government of India, New Delhi. http://www.moef.nic.in/sites/default/files/Pg01-52_0.pdf. Accessed 12 June 2018

Orchard SE, Stringer LC, Quinn CH (2016) Mangrove system dynamics in Southeast Asia: linking livelihoods and ecosystem services in Vietnam. Regional Environmental Change16:865-879

Ostrom E (1990) Governing the commons. Cambridge University Press, Cambridge

Ostrom E (2003) How types of goods and property rights jointly affect collective action. J Theor Politics 15(3):239-270

Parrotta JA, Trosper RL (2012) Traditional forest-related knowledge: sustaining communities, ecosystems and biocultural diversity. Springer, London
Pirard R, Penri H, Baral H (2017) Local impacts of industrial tree plantations: an empirical analysis in Indonesia across plantation types. Land Use Policy 60:242-253

Poffenberger M, Barik SK, Choudhary D, Darlong V, Gupta V, Palit S, Roy I, Singh I, Tiwari BK, Upadhyay S (2006) Forest sector review of northeast India. Background paper no. 12. http://siteresources.worldbank.org/ INTSAREGTOPWATRES/Resources/Background_Paper_12.pdf. Accessed 17 May 2017

Poffenberger M, Barik SK, Choudhury D, Darlong V, Gupta V, Palit S, Roy I, Singh I, Tiwari BK, Upadhyay S (2007) Indigenous forest stewards of northeast India. Community Forestry International, Antioch, CA 94531 USA. https://www. researchgate.net/publication/237475024_INDIGENOUS_FOREST_STEWARDS_ OF_NORTHEAST_INDIA. Accessed 30 June 2018.

Pretty J, Smith D (2004) Social capital in biodiversity conservation and management. Cons Biol 18(3):631-638

Ramakrishnan PS (2002) Land use dynamics and sustainable development in Arunachal Pradesh: environmental planning and Sustain Dev Himvikas. Occasional Publication, New Delhi

Ramakrishnan PS (2005) Mountain biodiversity, land use dynamics and traditional ecological knowledge. In: Huber UM, HKM B, Resoner MA (eds) Global change and mountain regions: an overview of current knowledge. Springer, the Netherlands, pp 551-561

Ramakrishnan PS (2007) Sustainable mountain development: the Himalayan tragedy. Curr Sci 92(3):308-316

Ramakrishnan PS, Das AK, Saxena KG (1996) Conserving biodiversity for Sustainable development. Indian National Science Academy, New Delhi, p 246

Sangha KK, Jalota RK (2005) Value of ecological services of exotic Eucalyptus tereticornis and native Dalbergia sissoo tree plantations of north-western India. Cons Society 3(1):92-109

Shepard GN, Yu DW, Uzarralde M, Iralano M (2001) Rainforest habitat classification among the Matsigenka of the Peruvian Amazon. J Ethnobiol 21(1):1-38

Shrestha UB, Shrestha BB, Shrestha S (2010) Biodiversity conservation in community forests of Nepal: rhetoric and reality. Int J Biodiversity Conservation 2(5):98-104

Singh AK, Arunachalam A, Ngachan SV, Mohapatar KP, Dagar JC (2014) From shifting cultivation to integrated farming: experiences of agroforestry development in the north-eastern Himalayan region. In: Dagar JC, Singh AK, Arunachalam A (eds) Agroforestry systems in India: livelihood security and ecosystem services. Springer, New Delhi, pp 57-63

Singh RK, Padung E (2010) Climate change, REDD and biocultural diversity: consultations and grassroots initiative with indigenous people of Arunachal Pradesh. Curr Sci 99 (4:421-422

Singh RK, Singh A, Garnett ST, Zander KK, Lobsang TD (2015b) Paisang (Quercus griffithii): a keystone tree species in sustainable agroecosystem management and livelihoods in Arunachal Pradesh, India. Environ Manag 55:187-204

Singh RK, Srivastava RC, Pandey CB, Singh A (2015a) Tribal institutions and conservation of the bioculturally valuable 'tasat' (Arenga obtusifolia) tree in the eastern Himalaya. J Environ Plan Manage 58(1):69-90

Sterling EJ, Betley E, Sigouin A, Gomez A, Toomey A, Cullman G, Malone C, Pekor A, Areng F (2017) Assessing the evidence for stakeholder engagement in biodiversity conservation. Biol Conserv 209(2017):159-171

Stringer LC, Reed MS, Fleskens L, Thomas RJ, Le OB, Lala-Pritchard T (2017) A new dryland development paradigm grounded in empirical analysis of dryland systems science. Land Degrad Deve 28(7):1952-1961

Turner NJ (2005) The Earth's blanket: traditional teachings for sustainable living. University of Washington Press, Washington, p 298

Turner NJ, Berkes F (2006) Coming to understanding: developing conservation through incremental learning in the Pacific northwest. Human Ecol 34(4):495-513

Turner NJ, Clifton H (2009) "It's so different today": climate change and indigenous lifeways in British Columbia, Canada. Glob Environ Chang 19(2):180-190 